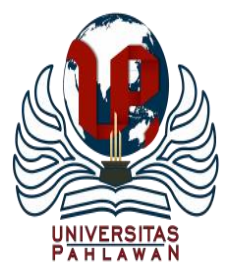

Edukatif : Jurnal Ilmu Pendidikan Volume 3 Nomor 3 Tahun 2021 Halm 1010 - 1021

EDUKATIF: JURNAL ILMU PENDIDIKAN

Research \& Learning in Education

https://edukatif.org/index.php/edukatif/index

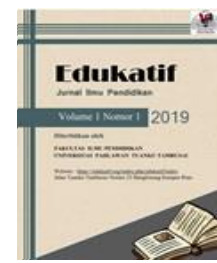

\title{
Efektivitas Model Pembelajaran Blended Learning dengan Pendekatan STEM Dalam Upaya Meningkatkan Kemampuan Berfikir Kritis Peserta Didik
}

\author{
Ika Wahyunita ${ }^{1}$, Waspodo Tjipto Subroto ${ }^{2}$ \\ Universitas Negeri Surabaya, Indonesia ${ }^{1,2}$ \\ E-mail : ika.17080554017@mhs.unesa.ac.id ${ }^{1}$, waspodosubroto@ unesa.ac.id ${ }^{2}$
}

\begin{abstract}
Abstrak
Hasil PISA tahun 2019 menyatakan pelajar Indonesia memiliki kemampuan berfikir kritis yang tergolong rendah. Sehingga perlu adanya model pembelajaran yang mendorong berkembangnya berfikir kritis yaitu blended learning dengan pendekatan STEM yang menekankan pembelajaran pada masalah dikehidupan nyata. Tujuan penelitian untuk mengetahui (1) keterlaksanaan pembelajaran blended learning dengan pendekatan STEM untuk meningkatakan kemampuan berfikir kritis, (2) peningkatan keterampilan berfikir kritis, dan (3) efektivitas model pembelajaran blended learning dengan pendekatan STEM terhadap kemampuan berfikir kritis. Subjek penelitian yang digunakan adalah kelas XI IPS 3 di SMAN 1 Puri dengan jumlah peserta didik 30 anak. Jenis penelitian ini yaitu eksperimen semu menggunakan rancangan one-group pretest-posttest. Data yang dikumpulkan yaitu hasil lembar keterlaksanaan pembelajaran, hasil tes kemampuan berfikir kritis, dan hasil respon peserta didik. Penelitian yang dilakukan mendapatkan hasil (1) keterlaksanaan pembelajaran berjalan dengan baik, (2) ketrampilan berfikir kritis peserta didik meningkat secara signifikan, dan (3) model pembelajaran blended learning dengan pendekatan STEM efektif untuk meningkatkan kemampuan berfikir kritis peserta didik. Dengan demikian dapat disimpulkan bahwa model pembelajaran blended learning dengan pendekatan STEM secara efektif dan signifikan dapat meningkatkan kemampuan berfikir kritis peserta didik. Kata Kunci: Model pembelajaran, blended learning, kemampuan berfikir kritis, Pendekatan STEM, STEM.
\end{abstract}

\section{Abstract}

The 2019 PISA results state that Indonesian students have low critical thinking skills. So it is necessary to have a learning model that encourages the development of critical thinking such as blended learning with a STEM approach that emphasizes learning on real-life problems. The research objectives were to determine (1) the implementation of blended learning with the STEM approach to improve critical thinking skills, (2) to increase critical thinking skills, and (3) the effectiveness of the blended learning model with the STEM approach to critical thinking skills. The research subjects used were class XI IPS 3 at SMAN 1 Puri with 30 students. This type of research is a quasi-experiment using a one-group pretest-posttest design. The data collected were the results of the learning implementation sheet, the results of the critical thinking skills test, and the results of the students' responses. The research conducted got the results (1) the implementation of learning went well, (2) the critical thinking skills of students increased significantly, and (3) the blended learning model with the STEM approach was effective to improve students' critical thinking skills. Thus it can be concluded that the blended learning model with the STEM approach can effectively and significantly improve students' critical thinking skills.

Keywords: Learning models, blended learning, critical thinking skills, STEM approach, STEM.

Copyright (c) 2021 Ika Wahyunita, Waspodo Tjipto Subroto

$\triangle$ Corresponding author

Email : ika.17080554017@mhs.unesa.ac.id

DOI : https://doi.org/10.31004/edukatif.v3i3.503

ISSN 2656-8063 (Media Cetak)

ISSN 2656-8071 (Media Online)

Edukatif : Jurnal Ilmu Pendidikan Vol 3 No 3 Tahun 2021 p-ISSN 2656-8063 e-ISSN 2656-8071 
1011 Efektivitas Model Pembelajaran Blended Learning dengan Pendekatan STEM Dalam Upaya Meningkatkan Kemampuan Berfikir Kritis Peserta Didik - Ika Wahyunita, Waspodo Tjipto Subroto DOI: https://doi.org/10.31004/edukatif.v3i3.503

\section{PENDAHULUAN}

Persiapan mendorong kemampuan peserta didik menghadapi tantangan industry 4.0 perlu adanya pengembangan ketrampilan peserta didik yang lebih dikenal dengan ketrampilan abad ke-21. Keterampilan abad 21 sangat dibutuhkan untuk mensukseskan globalisasi, perubahan pasar global, kompetensi internasional, migrasi, lingkungan politik, dan perkembangan teknologi. Frydenberg \& Andone mengungkapkan keterampilan abad 21 mencakup keterampilan dalam berfikir kritis, literasi digital, informasi, media, dan pemahaman serta penguasaan teknologi informasi dan komunikasi (Frydenberg \& Andone, 2011).

Berfikir kritis merupakan kemampuan memecahkan masalah dengan menggabungkan pengetahuan dalam sistem kognitif anak, sehingga dapat memilih solusi yang tepat (Cahyono, 2017). Kemampuan berfikir kritis sangat penting untuk dikembangkan karena peserta didik akan lebih mudah dalam menganalisis dan membuat argument yang kuat untuk membenarkan setiap keputusan berdasarkan bukti yang didapatkan dan hasil evaluasi yang dilakukan. Ennis dalam berfikir kritis memiliki beberapa indikator yang harus dikembangkan dikelompokkan dalam 5 aspek yaitu (1) aspek meberikan penjelasan sederhana memiliki indikator memfokuskan dan menganalisis pertanyaan dan bertanya serta menjawab pertanyaan yang membuatuhkan suatu penjelasan, (2) aspek membangun keterampilan dasar memiliki indikator mengobservasi dan mempertimbangkan laporan hasil observasi, (3) aspek membuat kesimpulan memiliki indikator menginduksi, mendeduksi, dan mempertimbangkan hasil induksi dan deduksi, (4) aspek membuat penjelasan lebih lanjut dengan indikator mendefisikan sebuah istilah dan mempertimbangkan definisi serta mengidentifikasi asumsi, dan (5) aspek membuat perkiraan dan integrasi dengan indikator berintegrasi dengan yang lain (Hidayat et al., 2016).

Indonesia menempati peringkat 71 dalam PISA pada tahun 2019 dengan rata-rata skor pada aspek kemampuan kinerja sains sebesar 396 poin, skor tersebut tergolong rendah (Tohir, 2019). Hubungan keterampilan berfikir kritis dan kemampuan kinerja sains cukup kuat dengan presentase $41,5 \%$ dan sisanya dipengaruhi faktor lain (Nugraha et al., 2017). Dengan demikian dapat dikatakan bahwa pelajar Indonesia memiliki kemampuan berfikir kritis masih rendah. Sejalan dengan penelitian Endang dkk dalam penelitiannya menganalisis tingkat ketrampilan berfikir kritis di SMA 1 Woha menyatakan bahwa sebanyak $21 \%$ peserta didik memiliki ketrampilan berfikir kritis sedang, 64\% ketrampilan berfikir kritis rendah, dan 15\% dengan kemampuan berfikir kritis tinggi (Susilawati et al., 2020).

Perkembangan kemampuan berfikir kritis dapat ditingkatkan dengan latihan terbimbing dan berulangulang (Rosnawati, 2012). Kurikulum 2013 merupakan upaya pemerintah dalam mengembangkan berfikir kritis karena standart kelulusannya menuntut ketrampilan berfikir kritis, kreatif, dan efektif sesuai dengan bakat dan minat (Susilawati et al., 2020). Hal ini sejalan dengan penelitian Nailul Khoiriyah mengungkapkan bahwa pembelajaran STEM (Science Technology Engineering Math) memperoleh taraf kepercayaan 95\% dan signifikan dalam membantu peserta didik untuk meningkatkan kemampuan berfikir kritis (Khoiriyah et al., 2018). STEM merupakan merupakan pendekatan yang terintegrasi, dimana dalam prosesnya dilaksanakan sebagai satu kesatuan yang dinamis (Brown et al., 2011). Pendekatan STEM menekankan pembelajaran pada masalah dikehidupan nyata untuk membiasakan dalam menemukan solusi tepat untuk setiap masalah dan dapat berfikir kreatif serta kritis. Memaksimalkan kinerja STEM yaitu teknologi, maka model blended learning cocok digunakan karena berbasis teknologi.

Whittaker menyatakan blended learning merupakan model pembelajaran gabungan antara pembelajaran daring dan tatap muka yang dikombinasikan pada aktivitas pembelajarannya maupun materi yang disampaikan (Sharma, 2010). Blended learning merupakan gabungan dari beberapa metode dan strategi pembelajaran yang dapat digunakan sebagai alternatif pembelajaran jarak jauh dengan menggabungkan pembelajaran tatap muka dengan pembelajaran daring (Istiningsih \& Hasbullah, 2015). Model pembelajaran blended learning secara signifikan juga mampu meningkatkan kemampuan peserta didik dalam berfikir kritis. 
1012 Efektivitas Model Pembelajaran Blended Learning dengan Pendekatan STEM Dalam Upaya Meningkatkan Kemampuan Berfikir Kritis Peserta Didik - Ika Wahyunita, Waspodo Tjipto Subroto DOI: https://doi.org/10.31004/edukatif.v3i3.503

Model pembelajaran blended learning terdapat empat ruang belajar yaitu sinkron langsung yaitu pembelajaran secara tatap muka dalam tempat dan waktu yang sama, sinkron virtual yaitu pembelajaran yang dilakukan dengan tatap muka melalui media virtual seperti video conference sehingga dilakukan dalam waktu yang sama namun tempat berbeda, asinkron mandiri merupakan pembelajaran secara mandiri yang dapat dilakukan kapanpun dan dimanapun sesuai dengan tujuan dan kemauan peserta didik, selanjutnya asinkron kolaboratif merupakan pembelajaran yang dapat dilakukan dimanapun dan kapanpun namun secara berkelompok (Chaeruman \& Maudiarti, 2018).

Penelitian ini dilaksanakan pada masa pandemi virus corona. Pedoman penyelanggaraan belajar dirumah dikeluarkan pemerintah pada surat edaran Kemendikbud nomer 04 tahun 2020 untuk mencegah penyebaran virus corona, maka kegiatan belajar mengajar secara tatap muka dihentikan dan diganti pembelajaran secara daring (Baety \& Munandar, 2021). Maka dari itu, model empat ruang belajar dalam pembelajaran blended learning tidak dapat dilaksanakan. Penerapan model pembelajaran blended learning memiliki tingkat fleksibilitas yang tinggi, seperti dapat dengan mudah menyesuaikan waktu yang dimiliki pendidik dan peserta didik. Dalam seminarnya, Chaeruman menjelaskan bahwa pada masa pandemi saat ini hanya ada tiga ruang saja yang dapat dilaksanakan yaitu sinkron virtual, asinkron mandiri, dan asinkron kolaboratif (Dwiyanto, 2020).

Penelitian ini mengacu pada penelitian Suji Ardianti bahwa model pembelajaran blended learning dengan pendekatan STEM dapat meningkatkan kemampuan berfikir kritis peserta didik (Ardianti et al., 2019). Namun pada penelitian tersebut model pembelajaran blended learning yang diterapkan dengan tatap muka secara langsung, sedangkan dalam penelitian ini memiliki keterbatasan kondisi yang mengharuskan pembelajaran tatap muka secara langsung menjadi tatap muka secara virtual menggunakan bantuan video conference seperti google meet atau zoom. Dengan demikian pada penelitian ini ingin mengatahui apakah model pembelajaran blended learning dengan menggunakan tiga ruang belajar dapat meningkatkan kemampuan berfikir kritis peserta didik secara signifikan. Mengingat kemampuan berfikir kritis peserta didik harus tetap dilatih secara terbimbing dan berulang-ulang untuk mengembangkan pola pikir peserta didik.

Tujuan penelitian ini untuk melihat (1) keterlaksanaan pembelajaran blended learning dengan pendekatan STEM untuk meningkatakan kemampuan berfikir kritis, (2) peningkatan keterampilan berfikir kritis peserta didik, dan (3) efektivitas model pembelajaran blended learning dengan pendekatan STEM terhadap kemampuan berfikir kritis

\section{METODE}

Desain dari penelitian ini yaitu eksperimen semu dengan rancangan one-group pretest-posttest design. Eksperimen semu (quasi experimental design) merupakan sebuah penelitian yang penempatan subjeknya tidak dipilih secara acak. Sedangkan one-group pretest-posttest design merupakan penelitian yang menggunakan soal pretest dan posttest hanya kepada satu kelompok saja. Penelitian ini dilakukan di SMAN 1 Puri, Mojokerto pada kelas XI IPS 3 dengan 30 anak. Penentuan subjek merupakan rekomendasi dari guru ekonomi dengan pertimbangan tertentu. Variable bebas penelitian ini yaitu model pembelajaran blended learning dengan pendekatan STEM, sedangkan kemampuan berfikir kritis peserta didik merupakan variabel terikat.

Keterlaksanaan pembelajaran diukur menggunakan lembar observasi yang diberikan kepada pengamat untuk menilai keterlaksanaan pembelajaran pada hari itu. Indikator dalam lembar keterlaksanaan pembelajaran disesuaikan dengan rencana pelaksanaan pembelajaran (RPP). Sedangkan analisis data keterlaksanaan pembelajaran dengan mendeskripsikan keterlaksanaan pada saat penelitian dan mencari skor rata-rata untuk lembar observasi.

Peningkatan keterampilan berfikir kritis diukur menggunakan soal yang disesuaikan dengan aspek kemampuan berfikir kritis menurut Enis dalam (Hidayat et al., 2016). Data hasil pretest dan posttest dianalisis menggunakan ketuntasan klasikan untuk mengetahui tuntas tidaknya dan uji $\mathrm{t}$ berpasangan untuk 
1013 Efektivitas Model Pembelajaran Blended Learning dengan Pendekatan STEM Dalam Upaya Meningkatkan Kemampuan Berfikir Kritis Peserta Didik - Ika Wahyunita, Waspodo Tjipto Subroto DOI: https://doi.org/10.31004/edukatif.v3i3.503

menunjukkan perbedaan rata-rata sebelum dan sesudah diterapkan model blended learning dengan pendekatan STEM terhadap kemampuan berfikir kritis.

Efektivitas model blended learning dengan pendekatan STEM terhadap kemampuan berfikir kritis diukur menggunakan indikator menurut Sriyanti (1) respon peserta didik terhadap model pembelajaran, (2) keaktifan peserta didik, (3) keterlaksanaan pembelajaran oleh guru, dan (4) hasil belajar peserta didik (Sriyanti, 2015). Respon peserta didik terhadap model pembelajaran blended learning dalam pernyataannya disesuaikan dengan indikator respon peserta didik menurut Keller (Kirna et al., 2015). Data respon peserta didik dianalisis menggunakan persentase respon pada setiap item pernyataan.

\section{HASIL DAN PEMBAHASAN}

Keterlaksanaan pembelajaran diukur menggunakan lembar observasi yang dibuat sesuai dengan RPP yang telah dikonsultasikan dan diamati oleh guru mata pelajaran ekonomi dan dosen pengamat. Dalam implementasi proses pembelajaran dengan blended learning perlu rancangan yang matang untuk menciptakan proses pembelajaran yang bermakna dan keterampilan pada peserta didik, sehinga pengamatan ini dilakukan untuk mengetahui karakteristik dari peserta didik. Pengamatan keterlaksanaan pembelajaran betujuan membandingkan RPP dengan proses pembelajaran yang dilakukan.

Tabel 1 Rata-Rata Skor Pengamatan RPP

\begin{tabular}{|c|c|c|c|c|}
\hline Pengamat & Skor perolehan & Skor maksimal & Rata-rata & Kategori \\
\hline Pengamat 1 & 93 & 110 & 84,55 & Cukup Baik \\
\hline Pengamat 2 & 97 & 110 & 88,18 & Sangat Baik \\
\hline
\end{tabular}

Sumber : Data Olahan Hasil Penelitian

Dari hasil kategori pengamatan, kedua pengamat menyatakan bahwa hasil sudah memadai untuk diterapkan dan dapat diuji cobakan dalam proses pembelajaran. Lembar observasi keterlaksanaan pembelajaran diberikan kepada observer sebelum dimulainya proses pembelajaran. Selama proses pembelajaran diamati guru mata pelajaran ekonomi di SMAN 1 Puri. Lembar observasi diisi sebanyak tiga kali sesuai dengan banyaknya jumlah pertemuan dalam penelitian. Aspek yang diamati pada lembar observasi yaitu pelaksanaan proses pembelajaran. Berikut rata-rata skor lembar observasi:

\section{Tabel 2 Rata-Rata Skor Keterlaksanaan Pembelajaran}

\begin{tabular}{|c|c|c|}
\hline Pertemuan & Rata-Rata Skor & Kategori \\
\hline $\mathbf{1}$ & $100 \%$ & Sangat Baik \\
\hline $\mathbf{2}$ & $100 \%$ & Sangat Baik \\
\hline $\mathbf{3}$ & $100 \%$ & Sangat Baik \\
\hline
\end{tabular}

Sumber : Data Olahan Hasil Penelitian

Pada tabel 3, rata-rata skor keterlaksanaan pembelajaran yang diamati oleh observer dalam kategori baik pada setiap pertemuan. Hal tersebut dikarenakan pelaksanaan pembelajaran sesuai dengan RPP, sehingga pembelajaran dapat dilaksanakan secara efektif.

Proses pembelajaran dilaksanakan pada setiap hari rabu untuk menyesuaikan dengan jadwal mata pelajaran ekonomi kelas XI IPS 3 dan malam sebelum proses pembelajaran dilaksanakan sebagai penerapan asinkronus mandiri. Penelitian pertama dilaksanakan pada tanggal 2 Maret 2021 pada saat malam hari dengan mengirimkan soal pre-test dan materi pembelajaran yang akan dibahas keesokan harinya. Proses pembelajaran dilanjutkan keesokan harinya dengan menerapkan seluruh langkah-langkah pembelajaran blended learning dengan pendekatan STEM. Penelitian kedua dilaksanakan pada tanggal 9 Maret 2021 dengan mengirimkan materi dan studi kasus yang akan dibahas keesokan harinya. Pembelajaran kemudian dilanjutkan pada keesokan harinya. Penelitian ketiga dilaksanakan pada tanggal 16 Maret 2021 dengan mengirimkan materi dan studi kasus yang akan dibahas keesokan harinya. Pembelajaran kemudian dilanjutkan pada keesokan harinya 
1014 Efektivitas Model Pembelajaran Blended Learning dengan Pendekatan STEM Dalam Upaya Meningkatkan Kemampuan Berfikir Kritis Peserta Didik - Ika Wahyunita, Waspodo Tjipto Subroto

DOI: https://doi.org/10.31004/edukatif.v3i3.503

pada tanggal 17 Maret 2021 dikarenakan ini pertemuan terakhir maka soal post-test dan kuisioner dibagikan kepada peserta didik untuk dikerjakan.

Pembelajaran yang dilaksanakan menggunakan model blended larning tiga ruang yaitu sinkronus virtual, asinkron mandiri, dan asinkron kolaboratif. Pada pembelajaran asinkronus mandiri guru menginformasikan tentang proses pembelajaran yang akan dilaksanakan keesokan harinya agar peserta didik lebih siap untuk memulai pembelajaran. Selanjutnya guru memberikan materi untuk dipelajari peserta didik terlebih dahulu agar pada saat pembelajaran tatap muka secara virtual peserta didik sudah memiliki sedikit pemahaman tentang materi yang akan dibahas dan dapat aktif pada proses pembelajaran. Guru menginstrupsikan kepada peserta didik untuk membentuk kelompok dengan tujuan mendiskusikan studi kasus yang telah diunggah guru pada google classroom, hal ini melatih kemampuan berdiskusi peserta didik. Jadi, pada pembelajaran asinkronus mandiri ini merupakan tahap persiapan untuk mendorong keaktifan peserta didik dan siap untuk melaksanakan pembelajaran pada keesokan harinya.

Pada pembelajaran sinkronus virtual dilaksanakan menggunakan aplikasi video conference yaitu google meet. Proses pembelajaran dilaksanakan pada pukul 07.00 dengan estimasi keterlambatan 15 menit dan selesai pada pukul 08.30. Pada pembelajaran sinkronus terdapat pendahuluan, kegiatan inti, dan penutup.

Tahap pendahuluan dibuka dengan guru mengintrupsikan untuk berdoa dan dilanjutkan memeriksa kehadiran. Guru kemudian memberikan motivasi peserta didik untuk tetap semangat dan tetap mematuhi protokol kesehatan yang telah disampaikan pemerintah agar dapat terhindar dari segala virus. Pada tahap ini guru menunjukkan tujuan pembelajaran dan mereview mengenai materi pembelajaran yang dilaksanakan pada pertemuan sebelumnya.

Pada tahap kegiatan inti terdapat dua fase yaitu akuisisi informasi, dan mensintesiskan pengetahuan. Pada fase akuisisi informasi sebelum guru menjelaskan materi pada pertumuan hari itu, guru terlebih dahulu mengajukan pertanyaan tentang materi yang telah dipelajari pada pembelajaran asinkronus mandiri untuk melatih aspek memberikan penjelasan sederhana (Leicester \& Taylor, 2010). Pada fase ini guru mengintrupsikan untuk menjelaskan apa yang telah dipahami terkait studi kasus yang telah diunggah guru, hal ini juga melatih kemampuan peserta didik pada aspek membuat penjelasan lebih lanjut. Selanjutnya pada fase mensintesiskan pengetahuan guru menyamakan pemahaman tentang konsep materi dan membuat kesimpulan materi yang dipelajari secara bersama-sama.

Tahap penutup guru menanyakan apakah ada yang ditanyakan mengenai materi yang dipelajari dan memberikan informasi mengenai studi kasus yang harus dikumpulkan peserta didik pada tahap pembelajaran asinkronus mandiri. Setelah semua pembelajaran telah dilaksanakan dan peserta didik tidak mengajukan pertanyaan maka pembelajaran akan ditutup dengan do'a.

Pada pembelajaran asinkronus mandiri setelah pembelajaran sinkronus dilaksanakan. Peserta didik berdiskusi secara virtual untuk menganalisis studi kasus. Hal ini dapat melatih kemampuan berfikir kritis pada aspek membuat penjelasan lebih lanjut. Pada tahap ini guru sebagai fasilitator apabila ada yang ditanyakan mengenai kejelasan tugas. Pembelajaran berakhir disaat peserta didik telah mengunggah jawaban studi kasus pada google classroom.

Pendekatan STEM dalam pembelajaran digunakan untuk melatih peserta didik menerapkan pengetahuan yang didapat dari sekolah terhadap permasalahan dikehidupan sehari-hari dengan mengintegrasikan subjek STEM dalam pembelajaran. STEM merupakan pendekatan yang terfokus pada peserta didik supaya dapat belajar mandiri sehingga membentuk logika berfikir dalam berbagai bidang pengetahuan dan mengembangkan kemampuan berfikir kritis. Literasi sains merupakan kemampuan seseorang dalam menganalisis informasi ilmiah dan mengimplementasikan pada kehidupan sehari-hari untuk mendapatkan solusi pemecahan masalah. Penerapan sains pada pembelajaran dilaksanakan dengan memberikan study kasus, peserta didik memahami dan menganalisis fenomena yang terdapat dalam study kasus tersebut. Literasi teknologi merupakan sebuah keterampilan dalam menggunakan, mengembangkan dan 
1015 Efektivitas Model Pembelajaran Blended Learning dengan Pendekatan STEM Dalam Upaya Meningkatkan Kemampuan Berfikir Kritis Peserta Didik - Ika Wahyunita, Waspodo Tjipto Subroto DOI: https://doi.org/10.31004/edukatif.v3i3.503

menganalisis teknologi untuk mengontruksikan pemikiran peserta didik. Implementasi teknologi pada pembelajaran dilakukan pada pembelajaran asinkron mandiri dan kolaboratif dengan menyajikan materi berbentuk video pembelajaran dan power point. Literasi teknik merupakan kemampuan untuk mengembangkan kreatifitas dan inovasi teknologi melalui penggabungan beberapa bidang ilmu. Teknik dalam pembelajaran dilakukan dengan membuat power point tentang permasalahan dalam study kasus dan diunggah pada google classroom. literasi matematika merupakan kemampuan untuk menganalisis serta mengungkapkan gagasan, pendapat, maupun rumusan secara matematik dalam pengimplementasiannya. Sedangkan matematika diimplementasikan melalui perhitungan perubahan harga barang dan jasa (Khoiriyah et al., 2018)

Gregorio mengungkapkan bahwa pengorganisasian dan berjalannya pembelajaran dikelas dapat menentukan keberhasilan pendidikan anak (Erwinsyah, 2016). Penelitian ini dapat diketahui bahwa keterlaksanaan pembelajaran blended learning dengan pendekatan STEM dapat berjalan dengan baik dengan rata-rata skor setiap pertemuan mencapai nilai $100 \%$ dalam kategori sangat baik yang membuktikan guru dapat mengelola kelas dan proses pembelajaran berjalan baik sehingga berdampak positif terhadap keberhasilan pendidikan.

Peningkatan kemampuan berfikir kritis dalam model blended learning dengan pendekatan STEM diukur dengan hasil pre-test dan post-test yang sinkron dengan indikator kemampuan berfikir kritis. Terdapat dua jenis soal dalam tes kemampuan berfikir kritis yaitu pilihan ganda dengan 15 soal dan uraian dengan 5 soal. Ennis berpendapat bahwa tes kemampuan berfikir kritis membutuhkan keterlibatan mental, membuat keputusan, strategi dan representasi, serta mempelajari konsep baru dalam memecahkan masalah yang lebih sesuai dengan tes uraian, namun McPeck menyatakan tes uraian dalam penilaian hasil tesnya menimbulkan subjektivitas, sehingga menurut Akbar soal pilihan ganda dapat digunakan dalam mengukur kemampuan berfikir kritis dengan memasukkan kemampuan HOT (Hight Order Thingking). Hal ini sesuai dengan pendapat Kartimi dan Liliasari bahwa melatih berfikir kritis peserta didik dapat dilakukan dengan memberikan soal latihan yang mengandunng aspek berfikir kritis (Mukti \& Istiyono, 2018).

Soal tersebut sebelum diujikan, terlebih dahulu ditelaah oleh dosen ahli dan diuji kelayakannya. Pada hasil validitas item pilihan ganda terdapat lima soal yang tidak valid, namun tidak menjadi permasalahan karena soal tersebut memiliki pasangan soal yang valid sehingga masih terdapat soal lain yang mewakili indikator, sedangkan untuk soal uraian semua soal dinyatakan valid. Pada uji reliabilitas soal pilihan ganda menunjukkan bahwa nilai dari cronbach's alpha $0.736>\mathrm{t}_{\text {tabel }} 0.514$, sedangkan soal uraian memiliki nilai cronbach's alpha $0.813>\mathrm{t}_{\text {tabel }} 0.514$ maka soal pilihan ganda dan uraian memiliki nilai konstant apabila digunakan untuk mengukur kemampuan berfikir kritits. Pada uji daya beda menunjukkan bahwa seluruh soal pilihan ganda dan uraian memiliki nilai daya beda dalam kategori diterima dengan baik, maka soal memiliki kemampuan dalam membedakan kemampuan peserta didik. Pada uji tingkat kesukaran kedua jenis soal memiliki rata-rata sedang. Sehingga peluang jawaban benar atau salah pada setiap soal tidak sukar dan tidak mudah. Memasukkan unsur HOT dalam soal dilakukan dengan membuat soal yang kontekstual serta menggunakan aspek memahami, menerapkan, dan menganalisis

Peningkatan kemampuan berfikir kritis diukur dengan melakukan pre-test sebagai patokan kemampuan awal peserta didik. Setelah dilakukan pre-test, peserta didik diberikan pembelajaran selama 3 kali pertemuan dan kemudian diberikan post-test. Hasil yang diperoleh menunjukkan tingkat perkembangan kemampuan berfikir kritis peserta didik. 
1016 Efektivitas Model Pembelajaran Blended Learning dengan Pendekatan STEM Dalam Upaya Meningkatkan Kemampuan Berfikir Kritis Peserta Didik - Ika Wahyunita, Waspodo Tjipto Subroto DOI: https://doi.org/10.31004/edukatif.v3i3.503

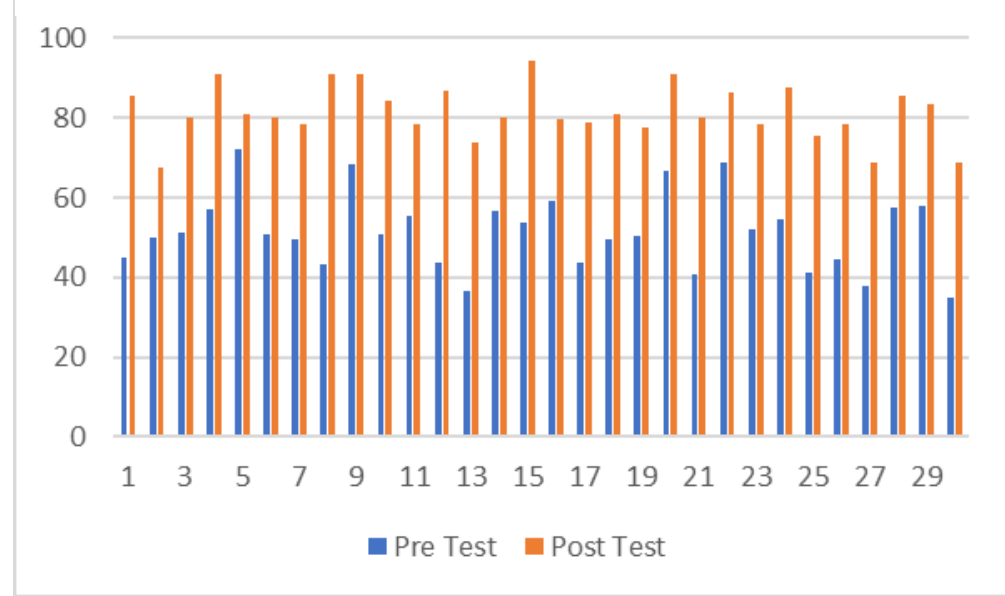

Gambar 1. Perbandingan Nilai Pre-test dan Post-test

Gambar diatas menunjukkan terdapat peningkatan kemampuan berfikir kritis sehingga dapat diketahui bahwa pelaksanaan pembelajaran model blended learning dengan pendekatan STEM mempermudah peserta didik dalam mengerjakan soal sehingga hasilnya semakin baik.. Saat peserta didik telah diberikan pembelajaran menggunakan model blended learning dengan pendekatan STEM ketuntasan klasikan yang diperoleh mencapai $83.3 \%$ dengan 25 anak yang mencapai nilai tuntas dan 5 lainnya memiliki nilai yang belum tuntas. Dua peserta didik yang mendapatkan nilai tidak tuntas tersebut dikarenakan tidak mengikuti pembelajaran pada hari pertama, sedangkan tiga peserta didik yang tidak tuntas dikarenakan kurang memperhatikan saat pembelajaran berlangsung sehingga sedikit kesusahan dalam mengerjakan soal. Muhli dalam bukunya menyatakan bahwa apabila sekurang-kurangnya $75 \%$ peserta didik mendapat nilai diatas KKM dapat dikatakan pembelajaran tersebut tuntas (Khotimah et al., 2018). Analisis perbedaan rata-rata berfikir kritis pada saat sebelum dilakukan model pembelajaran dengan sesudah diberikan model blended learning dengan pendekatan STEM menggunakan uji t berpasangan. Namun sebelumnya perlu dilaksanakan uji normalitas dan homogenitas.

Distribusi sampel atau subjek tergolong normal atau tidak dianalisis dengan uji normalitas. Subjek dinyatakan tidak normal apabila nilai signifikasi atau nilai probabilitas $<0,05$ dan apabila $>0,05$ maka distribusi subjek penelitian normal. Pada uji normalitas tingkat signifikansi uji normalitas Kolmogorov Smirnov pada soal pre-test yaitu $0.200>0.05$ sehingga distribusi subjek penelitian adalah normal. Sedangkan tingkat signifikansi uji normalitas Kolmogorov Smirnov pada soal post-test yaitu $0.180>0.05$ sehingga distribusi subjek penelitian adalah normal.

Uji homogenitas merupakan uji statistik variansi data pada satu atau lebih sampel adalah sama. Pengujian homogenitas menggunakan uji Levene dengan software SPSS. Pada uji Levene data dikatakan normal apabila tingkat signifikansi Levene statistik > 0.05, sedangkan apabila tingkat signifikansi Levene statistik $<0.05$ data tersebut dalam kategori variasi data yang tidak normal. Pada hasil uji homogenitas Levene statistik diketahui bahwa nilai signifikansinya $0.134>0.05$ sehingga variasi data dalam kategori normal atau signifikansi kedua data yang dibandingkan bersifat homogen.

Selanjutnya uji t berpasangan menggunakan nilai pre-test dan post-test dari subjek untuk dianalisis dampak dari pembelajaran model blended learning dengan pendekatan STEM. Ho ditolak apabila tingkat signifikansi $(2$ tailed $)<0.05$. 
1017 Efektivitas Model Pembelajaran Blended Learning dengan Pendekatan STEM Dalam Upaya Meningkatkan Kemampuan Berfikir Kritis Peserta Didik - Ika Wahyunita, Waspodo Tjipto Subroto DOI: https://doi.org/10.31004/edukatif.v3i3.503

Tabel 3 Korelasi Sampel Berpasangan

\begin{tabular}{|c|c|c|c|c|}
\hline \multicolumn{5}{|c|}{ Paired Samples Correlations } \\
\hline & & $\mathrm{N}$ & Correlation & Sig. \\
\hline Pair 1 & Pre Test \& Post Test & 30 & .514 & .004 \\
\hline
\end{tabular}

Sumber : Data Olahan Hasil Penelitian

Pada tabel dapat diketahui bahwa nilai korelasi pre-test dan post-test yaitu 0.514 yang menunjukkan ada hubungan kuat antara hasil belajar pre-test dan post-test.

Tabel 4 Hasil uji t berpasangan

\begin{tabular}{|c|c|c|c|c|c|c|c|c|c|}
\hline \multicolumn{10}{|c|}{ Paired Samples Test } \\
\hline & & \multicolumn{5}{|c|}{ Paired Differences } & \multirow[t]{3}{*}{$\mathrm{t}$} & \multirow[t]{3}{*}{$\mathrm{df}$} & \multirow{3}{*}{$\begin{array}{l}\text { Sig. (2- } \\
\text { tailed) }\end{array}$} \\
\hline & & \multirow[t]{2}{*}{ Mean } & \multirow[t]{2}{*}{$\begin{array}{l}\text { Std. } \\
\text { Deviat } \\
\text { ion }\end{array}$} & \multirow{2}{*}{$\begin{array}{c}\text { Std. } \\
\text { Error } \\
\text { Mea } \\
n\end{array}$} & \multicolumn{2}{|c|}{$\begin{array}{l}\text { 95\% Confidence } \\
\text { Interval of the } \\
\text { Difference }\end{array}$} & & & \\
\hline & & & & & Lower & Upper & & & \\
\hline Pai & Pre Test - & & 8.379 & 1.53 & - & -26.805 & -19.568 & 29 & .000 \\
\hline r 1 & Post Test & 29.933 & & 0 & 33.062 & & & & \\
\hline
\end{tabular}

Sumber : Data Olahan Hasil Penelitian

Nilai signifikansi dalam tabel diatas $0.00<0.05$ yang berarti selisih rata-rata kedua data berbeda sehingga Ho ditolak dan $\mathrm{H}_{1}$ diterima maka dari itu model blended learning dengan pendekatan STEM efektif untuk meningkatkan kemampuan berfikir kritis peserta didik. Sehingga dapat dianalisis bahwa peningkatan terjadi setelah diterapkannya model pembelajaran blended learning dengan pendekatan STEM yang mendorong meningkatnya kemampuan berfikir kritis peserta didik.

Proses pembelajaran yang terlaksana dengan baik menjadi salah satu faktor meningkatnya kemampuan berfikir kritis. Peningkatan kemampuan berfikir kritis dapat dilatih dengan latihan terbimbing yang berhubungan dengan masalah dalam kehidupan nyata dan disajikan sesuai perkembangan kognitif peserta didik (Rosnawati, 2012). Dengan dorongan dan bimbingan guru, peserta didik akan lebih aktif dalam membangun pemahamannya sendiri terhadap apa yang mereka terima. Penting bagi guru untuk membangun hubungan dengan peserta didik pada proses pembelajaran untuk menciptakan pembelajaran yang efektif. Dengan demikian dapat diketahui model pembelajaran blended learning dengan pendekatan STEM efektif dalam meningkatkan kemampuan berfikir kritis peserta didik.

Efektifitas model pembelajaran merupakan salah satu tolak ukur pendidikan dengan ketercapaian suatu tujuan dan ketepatan dalam mengelola proses pembelajaran. Efektifitas model pembelajaran sebagai tolak ukur pendidikan memiliki indikator (1) respon peserta didik terhadap model pembelajaran, (2) keaktifan peserta didik, (3)keterlaksanaan pembelajaran oleh guru, dan (4) Hasil belajar peserta didik.

Indikator respon dan keaktifan diukur menggunakan kuisioner yang disebar setelah rangkaian penelitian dilaksanakan. Pernyataan dalam kuisioner telah disesuaikan dengan indikator motivasi Keller. Dalam kuisioner respon peserta didik terdapat sepuluh pernyataan dengan pilihan jawaban menggunakan skala likert. Respon peserta didik diambil dengan memberikan kuisioner setelah keseluruhan penelitian selesai dengan responden sebanyak 30 peserta didik.

Sebelum kuisioner diberikan kepada peserta didik, kuisioner perlu untuk diuji validitas dan reliabilitas menggunakan software SPSS terlebih dahulu untuk mengetahui kelayakan instrumen untuk mengukuran data. Pada hasil uji validitas ada tiga pernyataan yang tidak valid, namun tidak menjadi permasalahan karena tiga pernyataan yang tidak valid tersebut memiliki pasangan pernyataan yang valid sehingga masih ada pernyataan lain yang mewakili indikator. Sedangkan dalam uji reliabilitas cronbach's alpha sebesar $0.733>\mathrm{t}_{\text {tabel }} 0.514$ maka pernyataan pada kuisioner respon peserta didik reliabel atau memiliki nilai konstant apabila digunakan untuk mengukur respon peserta didik. Sehingga dalam hasil uji validitas dan reliabilitas dinyatakan bahwa 
1018 Efektivitas Model Pembelajaran Blended Learning dengan Pendekatan STEM Dalam Upaya Meningkatkan Kemampuan Berfikir Kritis Peserta Didik - Ika Wahyunita, Waspodo Tjipto Subroto DOI: https://doi.org/10.31004/edukatif.v3i3.503

kuisioner pernyataan respon peserta didik valid dan reliabel. Rekapitulasi presentase respon peserta didik sebagai berikut:

Tabel 5 Presentase Respon Peserta Didik

\begin{tabular}{|c|c|c|c|}
\hline No & Keterangan & $\begin{array}{l}\text { Persentase } \\
\text { respon }\end{array}$ & Kategori \\
\hline 1 & $\begin{array}{l}\text { Pembelajaran ekonomi dengan menerapkan model blended } \\
\text { learning dengan pendekatan STEM menyenangkan. }\end{array}$ & 74,17 & Baik \\
\hline 2 & $\begin{array}{l}\text { Saya sudah pernah mengikuti pembelajaran dengan model } \\
\text { blended learning dengan pendekatan STEM. }\end{array}$ & 75,00 & Baik \\
\hline 3 & $\begin{array}{l}\text { Terlepas cocok atau tidak cocok, saya ingin mengikuti } \\
\text { pembelajaran dengan model blended learning dengan } \\
\text { pendekatan STEM }\end{array}$ & 85,00 & $\begin{array}{c}\text { Baik } \\
\text { Sekali }\end{array}$ \\
\hline 4 & $\begin{array}{l}\text { Model pembelajaran blended learning dengan pendekatan } \\
\text { STEM mempermudah saya dalam memahami materi sesuai } \\
\text { dengan cara belajar saya. }\end{array}$ & 78,33 & Baik \\
\hline 5 & $\begin{array}{l}\text { Model pembelajaran blended learning dengan pendekatan } \\
\text { STEM mempermudah saya dalam membuat kesimpulan yang } \\
\text { logis atas informasi yang saya temukan. }\end{array}$ & 80,00 & $\begin{array}{c}\text { Baik } \\
\text { Sekali }\end{array}$ \\
\hline 6 & $\begin{array}{l}\text { Dengan model pembelajaran blended learning dengan } \\
\text { pendekatan STEM saya lebih mudah mengingat materi. }\end{array}$ & 77,50 & Baik \\
\hline 7 & $\begin{array}{l}\text { Diskusi secara daring membuat saya sulit menyampaikan } \\
\text { pendapat. }\end{array}$ & 65,83 & Baik \\
\hline 8 & $\begin{array}{l}\text { Pembelajaran dengan model blended learning dengan } \\
\text { pendekatan STEM membuat saya kebingungan saat } \\
\text { pembelajaran berlangsung. }\end{array}$ & 67,50 & Baik \\
\hline 9 & $\begin{array}{l}\text { Pembelajaran ekonomi dengan menerapkan model blended } \\
\text { learning dengan pendekatan STEM tidak membantu saya dalam } \\
\text { belajar. }\end{array}$ & 77,50 & Baik \\
\hline 10 & $\begin{array}{l}\text { Saya lebih berperan aktif dikelas yang menerapkan model } \\
\text { blended learning dengan pendekatan STEM }\end{array}$ & 70,00 & Baik \\
\hline & rata - rata & 75,08 & Baik \\
\hline
\end{tabular}

Sumber : Data Olahan Hasil Penelitian

Pada tabel rekapitulasi respon peserta didik diketahui rata-rata respon mendapatkan nilai $75,08 \%$ dengan kategori baik, sehingga motivasi dalam mengikuti pembelajaran tinggi. Hal ini sejalan dengan Marzano yang mengungkapkan pembelajaran efektif dapat diketahui menggunakan sikap dan respon positif pada saat proses pembelajaran karena aspek tersebut menunjukkan ketertarikan pada pembelajaran yang mendorong usaha belajar (Kirna et al., 2015).

Tingkat persentase respon mendapat kategori baik dikarenakan semalam sebelum proses pembelajaran peserta didik diberikan informasi dan motivasi untuk mengikuti pembelajaran keesokan harinya. Selain itu peserta didik juga diberikan materi terlebih dahulu untuk dipelajari sehingga keesokan harinya peserta didik sedikit banyak sudah memahami materi yang disampaikan guru. Keesokan harinya sebelum pembelajaran sinkronus langsung dimulai guru kembali memberikan motivasi. Hal ini mendorong untuk lebih aktif dalam 
1019 Efektivitas Model Pembelajaran Blended Learning dengan Pendekatan STEM Dalam Upaya Meningkatkan Kemampuan Berfikir Kritis Peserta Didik - Ika Wahyunita, Waspodo Tjipto Subroto

DOI: https://doi.org/10.31004/edukatif.v3i3.503

proses pembelajaran karena hal-hal belum dipahami saat mempelajari materi dimalam hari akan ditanyakan pada saat proses pembelajaran belangsung.

Indikator keterlaksanaan pembelajaran oleh guru diukur menggunakan lembar observasi yang telah diisi oleh pengamat. Hasil dari observasi keterlaksanaan pembelajaran pada pertemuan pertama hingga ketiga memiliki rata-rata skor $100 \%$ dalam kategori sangat baik yang berarti guru mengajar sesuai dengan RPP sehingga keterlaksanaan pembelajaran dapat dilaksanakan dengan baik. Hal ini juga dikatakan oleh Callahn \& Clark bahwa RPP dapat menunjang efektifitas pembelajaran karena detail dari proses pembelajaran sudah dipikirkan secara matang (Zendrato, 2016).

Indikator hasil belajar peserta didik dimana soal yang diberikan mengacu pada indikator kemampuan berfikir kritis memiliki peningkatan yang signifikan serta ketuntasan klasikal mencapai 83,3\%. Hal ini menandakan bahwa setelah dilakukan pembelajaran blended learning dengan pendekatan STEM hasil belajar peserta didik meningkat secara signifikan serta kemampuan berfikir kritis meningkat secara signifikan. Sesuai dengan pendapat Caroselli bahwa hasil belajar dapat mempengaruhi berfikir kritis karena ketepatan dan kamampuan mengerjakan soal sama halnya menyelesaikan permasalahan sehingga melatih peserta didik berargumen (Nande \& Irman, 2021; Sari \& Dewi, 2017)

Dari penjabaran diatas dapat diketahui model pembelajaran blended learning dengan pendekatan STEM efektif untuk digunakan dan efektif dalam meningkatakan kemampuan berfikir kritis. Hal ini sejalan dengan penelitian Suji Ardianti bahwa model pembelajaran blended learning dengan pendekatan STEM dapat meningkatkan kemampuan berfikir kritis peserta didik (Ardianti et al., 2019).

Dengan demikian dapat diketahui bahwa meskipun model pembelajaran blended learning dengan pendekatan STEM dilaksanakan hanya menggunakan model tiga ruang belajar namun masih dapat meningkatkan kemampuan berfikir kritis peserta didik secara efektif dan signifikan. Hal ini diharapkan dapat menjadi acuan pendidik untuk dapat menerapkan model pembelajaran blended learning dengan pendekatan STEM dalam proses pembelajaran untuk dapat mendorong peningkatan kemampuan berfikir kritis peserta didik. Namun dalam penerapan penelitian ini memiliki keterbatasan fasilitas pembelajaran berupa smartphone/laptop, kuota serta koneksi internet. Apabila peserta didik tidak memiliki smartphone/laptop maka pembelajaran tidak dapat dilaksanakan karena aplikasi video conference hanya dapat diakses menggunakan smartphone/laptop. Aplikasi video conference merupakan aplikasi yang membutuhkan koneksi internet yang stabil dan baik agar tidak tersendat-sendat dan mengaganggu proses pembelajaran serta menghabiskan kuota yang cukup banyak.

\section{KESIMPULAN}

Berdasarkan hasil pembahasan pada penelitian dapat disimpulkan bahwa (1) keterlaksanaan pembelajaran model blended learning dengan pendekatan STEM terlaksana dengan sangat baik dengan hasil rata-rata skor pada lembar keterlaksanaan pembelajaran dalam kategori sangat baik, (2) model blended learning dengan pendekatan STEM dapat meningkatkan kemampuan berfikir kritis peserta didik secara signifikan yang ditunjukkan dengan hasil uji t berpasangan, (3) perhitungaan setiap indikator efektivitas model pembelajaran dalam kategori baik, sehingga model pembelajaran blended learning dengan pendekatan STEM dapat secara efektif meningkatkan kemampuan berfikir kritis peserta didik. Dari hasil penelitian tersebut dapat diketahui bahwa model pembelajaran blended learning dengan pendekatan STEM secara efektif dan signifikan dapat meningkatkan kemampuan berfikir kritis peserta didik meskipun menggunakan model tiga ruang belajar. Kemampuan berfikir kritis merupakan kemampuan dasar yang penting untuk dilatih dalam diri peserta didik. Sehingga perlu untuk meningkatkan hasil uji kemampuan berfikir kritis dengan membiasakan peserta didik untuk mengerjakan latihan soal yang berkaitan dengan masalah dalam kehidupan nyata, serta memaksimalkan hasil keterlaksanaan pembelajaran dengan memanfaatkan media pembelajaran interaktif. 
1020 Efektivitas Model Pembelajaran Blended Learning dengan Pendekatan STEM Dalam Upaya Meningkatkan Kemampuan Berfikir Kritis Peserta Didik - Ika Wahyunita, Waspodo Tjipto Subroto DOI: https://doi.org/10.31004/edukatif.v3i3.503

\section{DAFTAR PUSTAKA}

Ardianti, S., Sulisworo, D., \& Pramudya, Y. (2019). Efektivitas Blended Learning Berbasis Pendekatan Stem Education Berbantuan Schoology Untuk Meningkatkan Critical Thinking Skill Pada Materi Fluida Dinamik. Prosiding Seminar Nasional Pendidikan KALUNI, 2, 240-246. https://doi.org/10.30998/prokaluni.v2i0.67

Baety, D. N., \& Munandar, D. R. (2021). Analasis Efektifitas Pembelajaran Daring Dalam Menghadapi Wabah Pandemi Covid-19. EDUKATIF : JURNAL ILMU PENDIDIKAN, 3(3), 880-889. https://doi.org/https://doi.org/10.31004/edukatif.v3i3.476

Brown, R., Brown, J., Reardon, K., \& Merrill, C. (2011). Understanding STEM: Current perceptions. Technology and Engineering Teacher, 70(6), 5.

Cahyono, B. (2017). Analisis Ketrampilan Berfikir Kritis Dalam Memecahkan Masalah Ditinjau Perbedaan Gender. Aksioma, 8(1), 50. https://doi.org/10.26877/aks.v8i1.1510

Chaeruman, U. A., \& Maudiarti, S. (2018). Quadrant of Blended Learning: a Proposed Conceptual Model for Designing Effective Blended Learning. Jurnal Pembelajaran Inovatif, 1(1), 1-5. https://doi.org/10.21009/jpi.011.01

Dwiyanto, H. (2020). Menyiapkan Pembelajaran dalam Memasuki " New Normal " dengan Blended Learning. Pengembang Teknologi Pembelajaran LPMP Lampung, 2019, 1-9.

Erwinsyah, A. (2016). Pengelolaan Pembelajaran Sebagai Salah Satu Teknologi Dalam Pembelajaran. Tadbir: Jurnal Manajemen Pendidikan Islam, 4(2), 80-94.

https://journal.iaingorontalo.ac.id/index.php/tjmpi/article/view/442

Frydenberg, M., \& Andone, D. (2011). Learning for 21 st Century Skills. https://doi.org/10.1109/iSociety18435.2011.5978460

Hidayat, A., Rahayu, S., \& Rahmawati, I. (2016). Analisis Keterampilan Berpikir Kritis Siswa SMP Pada Materi Gaya dan Penerapannya. Pros. Semnas Pend. IPA Pascasarjana UM, 1, 1112-1119.

Istiningsih, S., \& Hasbullah, H. (2015). Blended Learning, Trend Strategi Pembelajaran Masa Depan. Jurnal Elemen, 1(1), 49. https://doi.org/10.29408/jel.v1i1.79

Khoiriyah, N., Abdurrahman, A., \& Wahyudi, I. (2018). Implementasi pendekatan pembelajaran STEM untuk meningkatkan kemampuan berpikir kritis siswa SMA pada materi gelombang bunyi. Jurnal Riset Dan Kajian Pendidikan Fisika, 5(2), 53. https://doi.org/10.12928/jrkpf.v5i2.9977

Khotimah, U. K., Ariani, T., \& Gumay, O. P. U. (2018). Efektivitas Model Pembelajaran Quantum Teaching terhadap Hasil Belajar Fisika Siswa SMA Negeri Jayaloka. Science and Physics Education Journal (SPEJ), 1(2), 103-110. https://doi.org/10.31539/spej.v1i2.255

Kirna, I. M., Sudria, I. B. N., \& Tegeh, I. M. (2015). Apa Respons Dan Harapan Siswa Sma Tentang Blended Learning? Jurnal Pendidikan Dan Pengajaran, 48(1-3), 15-26. https://doi.org/https://doi.org/10.23887/JPPUNDIKSHA.V48I1-3.6914

Leicester, M., \& Taylor, D. (2010). Critical Thinking Across the curriculum; Developing critical thinking skills, literacy and philosophy in the primary classroom.

Mukti, T. S., \& Istiyono, E. (2018). Instrumen Penilaian Kemampuan Berpikir Kritis Peserta Didik SMA Negeri Mata Pelajaran Biologi Kelas X. BIOEDUKASI: Jurnal Pendidikan Biologi, 11(2), 107-112. https://jurnal.uns.ac.id/bioedukasi/article/download/21624/pdf

Nande, M., \& Irman, W. A. (2021). Penerapan Model Pembelajaran Blanded Learning dalam Meningkatkan Hasil Belajar Siswa Sekolah Menengah Kejuruan. Edukatif: Jurnal Ilmu Pendidikan, 3(1), 180-187. https://doi.org/https://doi.org/10.31004/edukatif.v3i1.240

Nugraha, A. J., Suyitno, H., \& Susilaningsih, E. (2017). Analisis Kemampuan Berpikir Kritis Ditinjau dari Keterampilan Proses Sains dan Motivasi Belajar melalui Model PBL. Journal of Primary Education, 
1021 Efektivitas Model Pembelajaran Blended Learning dengan Pendekatan STEM Dalam Upaya Meningkatkan Kemampuan Berfikir Kritis Peserta Didik - Ika Wahyunita, Waspodo Tjipto Subroto DOI: https://doi.org/10.31004/edukatif.v3i3.503

6(1), 35-43.

Rosnawati, R. (2012). Berpikir kritis melalui pembelajaran matematika untuk mendukung pembentukan karakter siswa. Seminar Nasional Pendidikan, 1-9. http://staff.uny.ac.id/sites/default/files/penelitian/R. Rosnawati, Dra. M.Si./makalah_an_Rosnawati_UNY_29_Juni_2012_apload.pdf

Sari, D. P., \& Dewi, R. M. (2017). Pengaruh Keterampilan Berpikir Kritis Dan Berpikir Kreatif Terhadap Hasil Belajar Mata Pelajaran Ekonomi Kelas X Ips 1 Di Man Mojosari. Edisi Yudisium, 5(1), 1-8.

Sriyanti, A. (2015). Komparasi keefektifan pembelajaran matematika menggunakan model kooperatif tipe talking stick dengan tipe make a match pada siswa kelas vii smp lpp umi makassar. MaPan: Jurnal Matematika Dan Pembelajaran, 3(1), 20-29. https://doi.org/https://doi.org/10.24252/mapan.2015v3n1a3

Susilawati, E., Agustinasari, A., Samsudin, A., \& Siahaan, P. (2020). Analisis Tingkat Keterampilan Berpikir Kritis Siswa SMA. Jurnal Pendidikan Fisika Dan Teknologi, 6, 11. https://doi.org/10.29303/jpft.v6i1.1453

Tohir, M. (2019). Hasil PISA Indonesia Tahun 2018 Turun Dibanding Tahun 2015. 2018-2019. https://doi.org/10.31219/osf.io/pcjvx

Zendrato, J. (2016). Tingkat Penerapan Dalam Pelaksanaan Pembelajaran Di Kelas Suatu Studi Kasus di SMA Dian Harapan Jakarta. Jurnal Pendidikan Dan Kebudayaan Scholaria, 6(2), 58-73. https://doi.org/https://doi.org/10.24246/j.scholaria.2016.v6.i2.p58-73 